\title{
The Role of the School Committee in Improving the Quality of Education Management
}

\author{
Sarwo $^{1 *}$, Bukman Lian², Rohana ${ }^{2}$ \\ ${ }^{1}$ SMP Negeri 9 Ogan Komering Ulu \\ ${ }^{2}$ Universitas PGRI Palembang \\ *Corresponding author. Email: sarwo47@yahoo.co.id
}

\begin{abstract}
This study aims to describe the role of the school committee in improving the quality of education management at SMP Negeri 2 OKU. This research is qualitative. Respondents in this research were the head of the school committee, the principal, and the vice principal. Data collection techniques in this research are interviews, observation and documentation. The data analysis process started from examining all data from interviews and documentation studies, followed by conducting data reduction, presenting data into tables and verifying data to draw conclusions. The data validity technique used triangulation. Based on the results of research, the role of the school committee in improving the quality of education management at SMP Negeri 2 OKU are: (1) as a provider of considerations in determining school policies and programs, school work budget plans, school performance and facilities, (2) as a supporting agency in raising funds and educational resources from the society, (3) as a controlling agency, supervising education services in schools, (4) as a mediator (mediator agency), as a complaints follow-up, suggestions, criticisms, and aspirations come from the society.
\end{abstract}

Keywords: School Committee, Quality, Education Management.

\section{INTRODUCTION}

Based on the Minister of Education and Culture Decree No. 75 of 2016, in improving the quality of education management, the role of the school committee and the community is very much needed and from the community itself in providing assistance in the form of thoughts and ideas that are innovative and creative in nature for the progress of a school institution. Participation from the community is indeed very necessary in developing education in schools, because it is hoped that the school committee will not only provide concepts and discourses, but more willing to carry out their duties as a committee at SMP Negeri 02 OKU.

The school committee is a collection of several community leaders where each of members come from different circles in the interests of improving the quality of education in schools [1]. The purpose of the school committee's existence is not only to provide input or consideration, but the school committee also has a role and function to carry out its duties in advancing the school and actualizing it in the community.

Implementing the concept of the school committee itself is not easy, because it is seen from the various experiences that have occurred in the community [2]. The difficulty is not from the unclear concept of the school committee [4], but the culture of organization in the community has not yet developed. As a follow-up to the Minister of Education's Decree on School Committees, socialization activities and preparation of various operational guidelines for their implementation have been carried out. However, in reality the school committee organization is very important in order to improve the quality of education which will make a school institution more qualified.

Management is a process or framework, which involves guiding or directing a group of people toward organizational goals or real purposes [10]. Management is an activity, the implementation is "managing" administration, while the executor is called the manager [11]. Quality in general is a comprehensive description and characteristics of a field or service that shows the ability to satisfy expected or implied needs [12]. In the context of education, the notion of quality includes educational inputs, processes and / or outputs [13]. According to Sallis (2006) quality improvement is increasingly important for institutions used to obtain better control through their own efforts [4]. Good freedom must be matched with good accountability. Institutions must demonstrate that they are able to provide quality education to students. Quality is 
something that distinguishes between good and vice versa. This means that quality in education is something that distinguishes between success and failure [14]. Quality is the main problem that will ensure the development of schools in achieving status in the midst of increasingly fierce competition in the world of education.

SMP Negeri 2 OKU is one of the junior secondary high schools located in the East Baturaja District. This institution is in great demand by students. The number of students has been increasing from year to year, so there is a need for a school organization that is able to manage and develop this educational institution, namely by forming a School Committee organization because it is very much needed by the school. This is proven by the fact that committee meetings are always held in determining a number of strategic school policies. Committee meetings are held not only on the basis of an invitation from the school, but sometimes the committee also asks the school to hold a committee meeting if there are things and input from the community and student guardians that need to be conveyed.

Based on the results of observations made by researchers at SMP Negeri $02 \mathrm{OKU}$, there are several advantages that exist within the scope of the school, namely the existence of activities and programs that are already running, so in the minds of the community there is a growing sense of belief that in SMP Negeri 2 OKU has many achievements, so that the community's interest in sending their children to SMP 2 OKU is very high. In addition, with the existence of a well-written work program from the school committee, the school is asked to immediately enforce disciplinary regulations for students as well as superior programs considering that the achievements are constantly developing.

The current achievements of students at SMP Negeri 2 OKU are first place in the Yadika Cup futsal tournament at the OKU Regency level, first place in the dramband between students at the OKU district level, first place in the National Science Olympiad competition for SMP OKU Regency, first place in the FL2SN level. OKU Regency.

Based on the above background, this researchers are interested in conducting research with the title "The Role of School Committees in Improving the Quality of Education Management at SMP Negeri 2 OKU".

Based on the description above, the formulation of the problem in this study is as follows: 1) What is the role of the school committee in improving the quality of education management at SMP Negeri 2 OKU?, 2) What are the supporting factors and inhibiting factors for the role of the school committee in improving the quality of education management at SMP Negeri 2
OKU?

The objectives of this research are to: 1) Describe the role of the school committee in improving the quality of education management at SMP Negeri 2 OKU. 2) Analyze supporting factors and inhibiting factors for the role of the school committee in improving the quality of education management at SMP Negeri 02 OKU.

\section{METHODS}

This research was conducted using a qualitative approach, namely an approach by looking at the object of research as a system, it means that the object of research is seen as a unit consisting of related elements and describes the existing phenomenology [6].

Moleong defines a qualitative methodology as a research procedure that produces descriptive data in the form of written or spoken words from people and observable behavior. This approach is directed at a holistic setting and individual (whole), so it is not allowed to isolate individuals or organizations into variables and hypotheses but need to view them from necessity. Researchers used a qualitative approach in this study based on the opinion of [7]. Qualitative research has a number of characteristics that allow a researcher to obtain internal information, namely: first, emphasizing the natural setting and the researcher acts as a key instrument; second, this research is more concerned with the process than the product; third, this study seeks to reveal the world of meaning behind one's actions.

Based on the explanation above, as a characteristic of this qualitative approach, it is impossible for the researcher to represent it to other people in the research because the researchers themselves were the key instrument in extracting information from the research subject, and the informant subject in this research was the principal. The research subjects intended were the main actors who were carrying out their duties and responsibilities which could be observed from the displayed behavior. Behavior that is routinely shown to others in the form of approaches, activities, efforts, and roles that are articulated or actualized by research subjects. Then the researcher provided a qualitative and indepth explanation (Werstehen) about: the role of the school committee in improving the quality of education management.

\section{RESULTS AND DISCUSSION}

SMP Negeri 2 OKU is located in the city center with the address Jln. BLL Kulon N0. 0808 Baturaja, East Baturaja sub-district, OKU district, South Sumatra Province. It was established in 1960 with an operational permit in 1960, thus SMP Negeri 2 OKU has been 60 years old and 
has graduated many students from all over Indonesia.

The school committee is an independent agency that also participates in schools, the existence of the school committee is focused on helping to improve the quality of education management, so institutionally the school committee at SMP Negeri 2 OKU is expected to be able to carry out their duties and functions. It is in line with the Regulation of the Minister of Education No. 75 of 2016.

The role of the school committee as an advisory agency shows the response of the committee in improving the quality of education in schools. The school has to ask the school committee for consideration in determining school policies, programs and activities. One of them is by having excellent programs that the school institution wants to develop itself.

The role of the School Committee is as a Supporting Agency. Support for the implementation of education in schools can be in the form of thoughts, ideas, and personnel. If in the past the role of the committee was more of a supporter of funding, now the role of the committee is more emphasized on other aspects, especially in the context of implementing and improving the quality of education management.

The role of the school committee as a controller or supervisor that can be carried out by the school committee as detailed by Syaiful Sagala is in the following activities. 1) Asking the teacher and students whether the teaching and learning process is in accordance with the desired competency standard; 2) Monitoring the implementation of the Annual Work Plan and School Work Plan; 3) Participating in the preparation of RKT and RKS; 4) Monitoring the use of budgets originating from Operational School Fundings; 5) Controlling the welfare of teachers and education personnel; 6) Monitoring the teaching and learning process and student learning outcomes; 7) Supervising in the implementation of the national examination; 8) Supervising budget allocations relating to the implementation of teaching and learning activities.

In relation to the role of the committee as a mediator or liaison, the school itself is a social institution that cannot be separated from the community, on the other hand, the community cannot be separated from the school institution. Both have interrelated interests, schools are formal institutions in charge of educating, training and guiding future generations, while the community is the user of these educational services. The community hopes that school institutions are able to forge students into productive and quality human resources to develop community potential after they graduate.
Based on these facts, it can be concluded that of the four roles of the school committee, one of the roles that is very likely to be carried out is the role of the school committee as a provider of consideration and the role of mediator or liaison, while the other two roles are not maximally implemented, because in giving consideration, of course the school committee is based on the aspirations and information that develops in the community in the form of suggestions, and improvements which then become input for school progress.

The role of school committees is very important in education in the era of regional autonomy, because there are many things they can do to participate in improving the quality of education and not just determine the school education budget. However, the reality is that there is a barrier that limits the space for the committee to move in maximizing its role, so it is very necessary to empower this role so that it can be carried out properly, without causing differences of opinion between the committee and the principal in determining an educational policy. Thus, mutual trust grows between the school and the parents in particular and the community in general, thus making the learning atmosphere more conducive for students, the atmosphere of the work environment for educators to be comfortable and pleasant, the strategic plan that has been prepared from the start can going well, the realization of facilities and infrastructure that support learning and finally the educational goals that have been formulated will be easily achieved.

In improving the quality of education management at SMP Negeri 02 OKU, the role of the school committee is very important in order to develop a quality school. There are several factors in the role of the school committee, namely supporting factors and inhibiting factors. The supporting factors are the formation of the school committee by deliberation and consensus by the school, the cooperative relationship between the school and the school committee and strong support from the community.

The pattern of work relations between the school and the school committee is a cooperative relationship in which the two positions are not subordinates and superiors. The school principal is not authorized to give orders to the school committee and vice versa, but the school principal and committee administrators can carry out their respective roles with the same goal of advancing and improving the quality of education management in schools.

Based on the principle of the supporting factors above, the relationship between the committee and the principal at SMP Negeri 2 OKU does not experience difficulties, firstly it is because in the first point it is explained that from 
the process of forming committee administrators based on deliberation and consensus with the school, secondly it is because they are the people who understand the conditions of the school with limitations and advantages. However, in line with developments in the current era where schools now receive a lot of government grants in the form of Operational School Funding, BKSM and other funds, these three principles must be maintained.

The inhibiting factors for the role of the school committee in improving the quality of education management are the lack of knowledge of the school committee's duties and the lack of independence of the school committee [15]. Regarding the explanation of the inhibiting factors are as follows. 1) Knowledge of the school committee's duties is very minimal. The role of the school committee is contained in the Minister of Education and Culture Decree Number 75 of 2016, namely as the agency that participates in the process of consideration, supports, controls and becomes a liaison between the government and the community. If the four duties of the school committee are not carried out properly, the results will not run optimally. 2) Lack of independence of the school committee. In the Regulation of the Minister of Education Number 75 of 2016 Article 2 paragraph 3 it states that the school committee carries out its functions in a mutual, democratic, independent, professional manner. Seeing the membership composition of the school committee, there are several administrators who come from within the scope of the school, so in giving consideration to the decisions and policies of the school principal, as committee members are less professional, so there is still an impression that the school committee has no longer a close cooperative relationship with headmaster. The solution to empower committee members who come from outside the school, namely by taking part in advancing school institutions. 3) Due to the limited time available from school committee members. 4) Lack of coordination between the school and school committee members.

\section{CONCLUSION}

The role of the school committee in improving the quality of education management at SMP Negeri 2 OKU.

As an advisory agency, the role of the school committee at SMP Negeri 2 OKU as a partner of the school principal has given consideration in determining school policies and programs, school work budget plans, school performance and facilities. As a working partner, the principal has given his consideration in every plan and program that has been prepared by the school, including the development of extracurricular activities to accommodate the talents and interests of students, Providing input on the learning process to teachers, Providing input on the process of managing education in schools.

As a supporting agency, the role of the school committee in improving the quality of education management at SMP Negeri 2 OKU is in the form of financial support, energy and thoughts. For example, creating disciplinary application programs for teachers, students and employees in schools, improving the religious life of teachers, students and employees at school, providing prizes for high-achieving students, utilizing infrastructure in the school environment for learning, maximizing school operational budgets and encouraging their use accordingly. applicable provision. In addition, the school committee also provides support such as holding funds for parents of students based on the sincerity of the students' parents.

As a controlling agency, the school committee at SMP Negeri 2 OKU monitors the process of teaching and learning activities and student learning outcomes, supervises the implementation of national exams, and supervises budget allocations related to the implementation of teaching and learning activities.

As a mediator (mediator agency), the role of the school committee as a liaison with the community at SMP Negeri $02 \mathrm{OKU}$ is to provide reports to parents and the community about the use of finances and program implementation at school, formally coordinate to support activities within the school and outside the school. relating to students.

Supporting and inhibiting factors for the role of the school committee in improving the quality of education management at SMP Negeri 2 OKU

Factors supporting the role of the school committee in improving the quality of education management include mutual openness between the school committee and the school so that the school does not feel supervised, the realization of the cohesiveness of the parents or guardians of students in implementing the results of the agreement to support school programs, communication and coordination that have been well established and harmony between the school and the school committee, the formation and selection of school committees based on joint deliberations and carried out in a family manner, the cooperative relationship between the committee and the school principal because both are partnerships, not superiors and subordinates and strong support for the school, especially in the form of infrastructure and in the learning process activities.

Factors inhibiting the role of the school committee in improving the quality of education management include the lack of knowledge of the 
school committee's duties due to the lack of information on the scope of the school committee's task distribution and the lack of independence and professionalism of the school committee where this is because most people who are elected to the school committee are really loyal to the school principal so that there is little possibility to criticize or evaluate the performance of the school principal and because of the minimal time available from school committee members and a lack of coordination and some committee members do not have time to actively organize, due to the different backgrounds of school committee members and have their respective jobs.

\section{REFERENCES}

[1] Government Regulation Education and Culture No. 75 of 2016.

[2] Terry and Rue, (2000). Management Basics, trans. GA Ticoalu. Print. Seventh, Bumi Aksara, Jakarta.

[3] Depdiknas, 2001 School Based Quality Improvement Management, Depdiknas, Jakarta.

[4] Sallis Edward, 2006 Total Quality Management in Education; Education Quality Management, trans. Ahmad Ali Riyadi, et.al., IRCiSoD, Yogyakarta.

[5] Ministry of National Education. 2000, School Based Quality Improvement Management, Student Library, Jakarta.

[6] Arikunto, Suharsimi. 2006. The research procedure is a practical approach. Jakarta: Rineka Cipta

[7] Meleong, Lexy J. 2013. Qualitative Research Methodology, Revised Edition. Bandung: Youth Rosdakarya.

[8] Bogdan and Biklen (in Meleong: 2013, 4 - 5) Qualitative Research Methodology, Revised Edition. Bandung: Youth Rosdakarya.

[9] Government Education and Culture Regulation No. 75 of 2016.

[10] Terry and Rue, (2000). Management Basics, trans. GA Ticoalu. Print. Seventh, Bumi Aksara, Jakarta.

[11] Ramadina, E. (2021). Aktualisasi Supervisi Artistik dalam Manajemen Pendidikan Islam. Attractive: Innovative Education Journal, 3(1), 91-101.

[12] Annur, S., \& Suhono, S. (2019). IMPLEMENTASI Manajemen pergruruan tinggi (studi kasus pada ptkis kopertais wilayah vii sumatera selatan). JMKSP (Jurnal Manajemen, Kepemimpinan, dan Supervisi Pendidikan), 4(1), 67-75.

[13] Asnawan, A. (2021). Enhancement Integrated Quality Management in Islamic Education Institutions. Bulletin of Science Education, 1(1), 42-49.
[14] Romlah, O. Y., \& Latief, S. (2021). Empowering the Quality of School Resources in Improving the Quality of Education. Bulletin of Science Education, 1(1), 37-41.

[15] Sarni, S., \& Muslimah, M. (2021). The Commendable Leadership in Islamic Perspective. Bulletin of Pedagogical Research, 1(1), 163-173. 